\title{
INNOVATION OF ISLAMIC BANKING INDUSTRY AS AN ALTERNATIVE ISLAMIC ECONOMIC DEVELOPMENT IN INDONESIA
}

\author{
Nurhani Fithriah dan Renny Supriyatni B. \\ Universitas Padjajaran \\ nurhanifithriah99@gmail.com
}

\begin{abstract}
Abstrak
alah satu bentuk penggalian potensi dan wujud kontribusi masyarakat dalam perekonomian nasional, adalah pengembangan sistem ekonomi berdasarkan nilai Islam (Syariah) dengan mengangkat prinsip-prinsipnya ke dalam Sistem Hukum Nasional. Prinsip Syariah berlandaskan pada nilai-nilai keadilan, kemanfaatan, keseimbangan, dan keuniversalan (rahmatan lil 'alamin). Nilai-nilai tersebut diterapkan dalam pengaturan perbankan yang didasarkan pada Prinsip Syariah yang disebut Perbankan Syariah. Prinsip Perbankan Syariah merupakan bagian dari ajaran Islam yang berkaitan dengan ekonomi. Selain itu, untuk memberikan keyakinan pada masyarakat yang masih meragukan kesyariahan operasional Perbankan Syariah selama ini, diatur pula kegiatan usaha yang tidak bertentangan dengan Prinsip Syariah meliputi kegiatan usaha yang tidak mengandung unsur-unsur riba, maisir, gharar,haram, dan zalim. Pengaturan tersendiri bagi Perbankan Syariah merupakan hal yang mendesak dilakukan, untuk menjamin terpenuhinya prinsip-prinsip Syariah, prinsip kesehatan Bank bagi Bank Syariah, dan yang tidak kalah penting diharapkan dapat memobilisasi dana dari negara lain yang mensyaratkan pengaturan terhadap Bank Syariah. Permasalahan yang dihadapi, bagaimanakah strategi dan kendala-kendala yang dihadapi dalam Inovasi Produk Industri Perbankan Syariah dalam mengembangkan perekonomian di Indonesia berdasarkan Undang-Undang Perbankan Syariah. Penelitian ini bertujuan mencari dan menemukan dalam praktik mengenai cara-cara dan bentuk-bentuk inovasi produk perbankan syariah, serta kendala-kendala yang dihadapinya. Penelitian ini, bersifat deskriptif analitis dan pendekatan yuridis normatif, serta bertujuan untuk memberikan gambaran secara lengkap dan sistematis mengenai fakta penerapan Bagi Hasil pada bank syariah. Selanjutnya data dianalisis melalui ketentuan perundang-undangan yang berlaku, dimana antara satu dengan yang lainnya tidak boleh saling bertentangan, memperhatikan khierarkhi dengan tujuan untuk mewujudkan kepastian hukum, dengan mencari dan menggali hukum yang hidup di dalam masyarakat, baik itu yang tertulis maupun tidak tertulis (Hukum Islam). Hasil penelitian menunjukkan bahwa, strateginya yaitu mengeluarkan produkproduk inovasi industri perbankan syariah, meningkatkan Sumber Daya Insani SDI), dan pemasaran produk yang secara strategis. Kendala-kendala yang dihadapi dalam Inovasi Produk Industri Perbankan Syariah dalam mengembangkan perekonomian di Indonesia, adalah sangat sulit untuk dilakukan karena terpaku pada prinsip syariah. Saran diajukan, sebaiknya melakukan sosialisasi produk-produk inovatif kepada masyarakat dan perangkat bank syariah mengefektifkan pengawasan (Internal \& ekstenal).
\end{abstract}

Kata Kunci: Inovasi, Perbankan Syariah, dan Ekonomi Indonesia

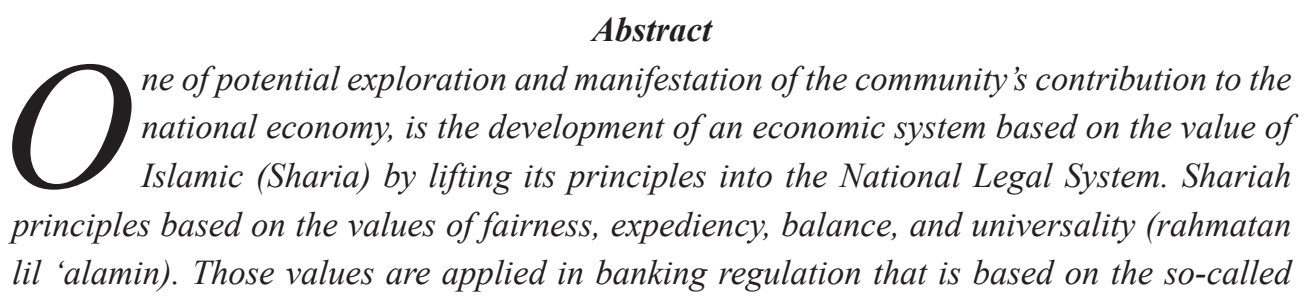




\begin{abstract}
Sharia Islamic Banking. Principles of Islamic Banking is part of Islamic teachings related to the economy. In addition, to provide assurance to the people who still doubt shariah Islamic Banking operations during this time also set of business activities that do not conflict with Sharia Principles include business activities that do not contain elements of riba, maisir gharar, haram, and zalim. A separate regulation for Islamic Banking is an urgent thing to do, to ensure compliance with Shariah principles, the principles of the Bank for Islamic Bank, and no less important is expected to mobilize funds from other countries that requires the regulation of the Islamic Bank. Problems faced, how the strategy and the constraints faced in Islamic Banking Industry Product Innovation in developing the economy in Indonesia by Islamic Banking Act. This study aims to look for and find in the practice of the ways and forms of Islamic banking product innovation, as well as the constraints that it faces. This research, analytical, descriptive and normative juridical approach, and aims to provide a complete picture of the facts and the systematic application of Sharing in Islamic banks. Furthermore, the data were analyzed through statutory provisions in force, which among one another should not be contradictory, pay attention to the hierarchy with the aim to achieve legal certainty, by searching and digging law who live in the community, whether it is written or unwritten (Islamic law). The results showed that the strategy which remove products of Islamic banking industry innovation, improve human resources SDI), and marketing of products strategically. Constraints faced in Islamic Banking Industry Product Innovation in developing the economy in Indonesia, it is very difficult to do because fixated on Islamic principles. Suggestions put forward, should disseminate innovative products to the public and the effectiveness of supervision of Islamic banks (Internal \& ekstenal).
\end{abstract}

Key words: Innovation, Islamic Banking and Economics Indonesia

\title{
Latar Belakang
}

Industri perbankan syariah saat ini banyak diminati oleh masyarakat Indonesia. Bahkan peminat perbankan syari'ah cenderung meningkat dari tahun ke tahun. Hal itu disebabkan karena perbankan syariah dinilai sangat menjanjikan dan tidak merugikan bagi para nasabahnya. Selain itu prospek kedepan juga dinilai jelas dan tidaklah mengecewakan. Sehingga semakin bertambah tahun, peranan industri perbankan syariah semakin urgen bagi masyarakat Indonesia. Karakteristik sistem perbankan syariah yang beroperasi berdasarkan prinsip bagi hasil memberikan alternatif sistem perbankan yang saling menguntungkan bagi masyarakat dan bank, serta menonjolkan aspek keadilan dalam bertransaksi,investasi yang beretika, mengedepankan nilai-nilai kebersamaan dan persaudaraan dalam berproduksi, dan menghindari kegiatan spekulatif dalam bertransaksi keuangan.

Bagi Hasil (Profit and Loss Sharing) dalam perbankan Syariah yang membedakannya dengan Bank Konvensional yang menganut Sistem Bunga (Interest) dalam setiap transaksinya. Di samping itu prinsip bank syariah sangat memperhatikan asas kemaslahatan bagi orang banyak (Maslahah al-ammanah). ${ }^{1} 1 \mathrm{Hal}$ mendasar yang membedakan antara Bank Syariah dan Bank Konvensional adalah terletak pada pengembalian dan pembagian keuntungan yang diberikan oleh nasabah kepada bank dan/atau yang diberikan oleh bank kepada nasabah. Sehingga terdapat istilah bunga dan bagi hasil. Untuk merealisasikan hal tersebut, sekarang pemerintah dan masyarakat khususnya yang beragama Islam telah mencoba mengembangkan paradigma perekonomian yang akan terus dikembangkan dalam rangka perbaikan ekonomi dan kesejahteraan umat. Caranya adalah berupa operasinya bank-bank syariah di Indonesia, dengan tidak mendasarkan pada bunga, namun dengan bagi hasil.

1 Muhamad, "Bank Syariah Analisis Kekuatan, kelemahan, Peluang dan Ancaman", Ekonisia, Yoyakarta, Cet. Ketiga, 2004, hlm. 58. Adiwarman Karim, Ekonomi Islam Suatu Kajian Kontemporer, Gema Insani Press, Jakarta, 2001, hlm. 173. Sebagaimana dikutip dari: Renny Supriyatni B., Sistem Bagi Hasil Dengan Pembagian Untung dan Rugi, Dapat Memberi Keadilan Bagi Nasabah \& Bank Syariah, Unpad Press, Bandung, 2009, hlm. 1. 
Bank Syariah menyediakan beragam produk, dan layanan jasa perbankan yang beragam dengan skema keuangan yang lebih bervariatif. Perbankan syariah menjadi alternatif system perbankan yang kredibel dan dapat diminati oleh seluruh golongan masyarakat Indonesia tanpa terkecuali. Dalam konteks pengelolaan perekonomian makro, meluasnya penggunaan berbagai produk dan instrument keuangan syariah dapat merekatkan hubungan antara sektor keuangan dengan sektor riil serta menciptakan harmonisasi di antara kedua sektor tersebut. Semakin meluasnya penggunaan produk dan instrumen syariah disamping akan mendukung kegiatan keuangan dan bisnis masyarakat juga akan mengurangi transaksi-transaksi yang bersifat spekulatif, sehingga mendukung stabilitas sistem keuangan secara keseluruhan, yang pada gilirannya akan memberikan kontribusi yang signifikan terhadap pencapaian kestabilan harga jangka menengah-panjang.

Urgensitas industri perbankan syariah di Indonesia, setidaknya mencakup empat hal, yakni sebagai alternatif jasa keuangan, transaksi non spekulatif, reattachment, dan fungsi sosial. Perkembangan industri perbankan syariah yang semakin tahun, semakin meningkat harus diimbangi dengan inovasi produk-produk perbankan syariah agar stabilitas perbankan syariah dalam eksistensinya mengembangkan perekonomian Indonesia agar tetap stabil. Indonesia terlebih saat ini, sedang mengadapi Masyarakat Ekonomi Asean (MEA) ${ }^{2} 2$ tentunya yang menjadi persaingan bukan hanya dari tingkat nasional tetapi juga tingkat internasional. Oleh karena itu perlu adanya setrategi-setrategi inovasi yang harus dibangun oleh perbankan syariah supaya mampu bersaing dengan berbankan nasional maupun internasional. Berdasarkan latar belakang tersebut di atas, penulis tertarik meneliti dan membahas tentang strategi inovasi produk industi perbankan syariah yang permasalahannya didentifikasi, sebagai berikut, bagaimanakah strategi dan kendala-kendala yang dihadapi dalam Inovasi Produk Industri Perbankan Syariah dalam mengembangkan perekonomian di Indonesia berdasarkan Undang-Undang Perbankan Syariah?

\section{Inovasi Produk Dan Industri}

Inovasi adalah salah satu pilihan korporasi dalam menghadapi persaingan pasar dan pengelolaan yang berkelanjutan. Inovasi dianggap sebagai upaya dari perusahaan melalui penggunaan teknologi dan informasi untuk mengembangkan, memproduksi dan memasarkan produk yang baru untuk industri. ${ }^{3} 3$ Dengan kata lain inovasi adalah modifikasi atau penemuan ide perbaikan secara terus-menerus dan pengembangan untuk memenuhi kebutuhan pelanggan. Inovasi perusahaan dapat menghasilkan Research and Development (R\&D), produksi dan pendekatan pemasaran serta akhirnya mengarah kepada komersialisasi inovasi tersebut. Inovasi merupakan proses mewujudkan ide baru, yang berbeda dengan yang dulu, dengan cara produksi atau dengan membuatnya menjadi nyata, dimana inovasi termasuk generasi evaluasi, konsep baru dan implementasi.

Penggunaan metode baru dan berbeda serta teknologi untuk meningkatkan kualitas biaya atau lebih rendah, untuk memenuhi atau melampaui target perusahaan. ${ }^{4} 4$ Inovasi tidak hanya terbatas pada benda atau barang hasil produksi, tetapi juga mencakup sikap hidup, perilaku, atau gerakan-gerakan menuju proses perubahan di dalam segala bentuk tata kehidupan masyarakat. Jadi, secara umum, inovasi berarti suatu ide, produk, informasi teknologi, kelembagaan, perilaku, nilai-nilai, dan praktik-praktik baru yang belum banyak diketahui, diterima, dan digunakan atau diterapkan oleh sebagianbesar warga masyarakat dalam suatu lokalitas tertentu, yang dapat digunakan atau mendorong terjadinya perubahan-perubahan di segala aspek kehidupan masyarakat demi terwujudnya perbaikan mutu setiap individu dan seluruh warga masyarakat

2 Tedjasuksmana, Budianto. 2014. Potret Indonesia Menghadapi Masyarakat Ekonomi ASEAN 2015. Jurnal UKWMS. ISSN No: 1978-6522.

3 Freeman, R E, 1984, Strategic Management : A Stakeholder Aproach, Bpston, Ma Pitman, hlm 461.

4 Pervaiz K. Ahmed and Charles D. Shepherd, 2010, Internal Marketing, Routlege, hlm 771. 
yang bersangkutan. 5

Selanjutnya Industri secara umum adalah suatu kegiatan mengolah bahan mentah atau bahan barang setengah jadi menjadi barang jadi yang memiliki nilai tambah untuk mendapatkan keuntungan. Menurut Undang-Undang No 5 Tahun 1984 tentang perindustrian, Industri adalah kegiatan ekonomi yang mengolah bahan mentah, bahan baku, barang setengah jadi, dan/atau barang jadi menjadi barang dengan nilai yang lebih tinggi untuk penggunaannya, termasuk kegiatan rancang bangun dan perekayasaan industri. Industri identik dengan sebuah perusahaan. Memang benar, tapi setiap perusahaan tidak harus besar dan menggunakan mesin. Kata Industri berasal dari bahasa latin, yakni industria yang artinya buruh atau tenaga kerja. Industri juga bisa diartikan sebagai semua bentuk kegiatan manusia dalam bidang ekonomi yang bersifat produktif untuk memenuhi kebutuhan hidup manusia dan mendapatkan keuntungan dari barang produksi yang dihasilkan. ${ }^{6} 6$ Menurut Badan Pusat Statistik (2015), Industri merupakan sebuah kesatuan unit usaha yang menjalankan suatu aktivitas ekonomi yang bertujuan untuk menghasilkan barang maupun jasa yang berdomisili pada suatu tempat atau lokasi tertentu dan memiliki catatan administrasi masing-masing.

Industri memiliki arti secara mikro dan makro. Secara mikro, Industri adalah kumpulan dari perusahaan-perusahaan yang menghasilkan barang-barang yang homogen atau barangbarang yang mempunyai sifat yang saling mengganti sangat erat. ${ }^{7} 7$ Dari segi makro, Industri adalah kegiatan ekonomi yang menciptakan nilai tambah. Industri adalah kegiatan ekonomi yang mengolah bahan mentah, bahan baku, barang setengah jadi, dan atau barang jadi menjadi barang dengan nilai yang lebih lagi penggunaannya, termasuk kegiatan rancang bangun industri dan perekayasaan industri. ${ }^{8} 8$

\section{Faktor Penunjang Dan Manfaat Inovasi}

Inovasi tidak hanya berurusan dengan pengetahuan baru dan cara-cara baru, tetapi juga dengan nilai-nilai karena harus bisa membawa hasil yang lebih baik, jadi selain melibatkan iptek baru, inovasi juga melibatkan cara pandang dan perubahan sosial. Inovasi dapat memberikan beberapa manfaat sebagai berikut ${ }^{9} 9$ :

1. Peningkatan kualitas hidup manusia melalui penemuan-penemuan baru yang membantu dalam proses pemenuhan kebutuhan hidup manusia.

2. Memungkinkan suatu perusahaan untuk meningkatkan penjualan dan keuntungan yang dapat diperolehnya.

3. Adanya peningkatan dalam kemampuan mendistribusikan kreativitas kedalam wadahpenciptaan sesuatu hal yang baru.

4. Adanya keanekaragaman produk dan jenisnya didalam pasar.

Inovasi dapat ditunjang oleh beberapa factor pendukung seperti: (a) Keinginan untuk merubah diri, dari tidak bisa menjadi bisa dan dari tidak tahu menjadi tahu. (b) Adanya kebebasan untuk berekspresi. (c) Adanya pembimbing yang berwawasan luas dan kreaktif (d). Tersedianya sarana dan prasarana. (e) Kondisi lingkungan yang harmonis, baik lingkungan keluarga, pergaulan, maupun sekolah.

$5 \quad$ Pervaiz K. Ahmed and Charles D. Shepherd, Ibid.

6 Prayoga, Ayudha D, et all, 1999, Industri dan Hukum yang Mengatur di Indonesia, Jakarta : ELIPS, hlm, 56.

7 Arsyad, Lincolin, 2007, Clustering Industri, Pengantar Perencanaan dan Pembangunan Ekonomi Daerah, BPFE, Yogyakarta, hlm 87.

8 Dirdjojuwono, Roestanto W, 2003, Kawasan Industri Indonesia (Sebuah Konsep Perencanaan Dan Aplikasinya), Pustaka Wirausaha Muda, Bogor, hlm 22.

9 Ibid. 


\section{Perbankan Syariah}

Berdasarkan Undang-undang Nomor 21 Tahun 2008 Tentang Perbankan Syariah (selanjutnya ditulis UUPS) Pasal 1 Ayat (1), dijelaskan bahwa, Perbankan Syariah adalah segala sesuatu yang menyangkut tentang Bank Syariah dan Unit Usaha Syariah, mencakup kelembagaan, kegiatan usaha, serta cara dan proses dalam melaksanakan kegiatan usahanya. Pada ayat selanjutnya disebutkan mengenai produk perbankan syariah. Akad yang dipergunakan diantaranya adalah akad wadi'ah atau Akad lain yang tidak bertentangan dengan Prinsip Syariah dalam bentuk Giro, Tabungan, atau bentuk lainnya yang dipersamakan dengan itu. Pada Peraturan Bank Indonesia 10/16/PBI/2008 Tentang Perubahan Peraturan Bank Indonesia Nomor 9/19/PBI/2007 Tentang Pelaksanaan Prinsip Syariah (selanjutnya ditulis PBI) Dlm kegiatan Penghimpunan Dana Dan Penyaluran Dana Serta Pelayanan Jasa Bank Syariah (selanjutnya ditulis PBI) dan SEBI No.10/14/DPbS Perihal Prinsip syariah Dlm kegiatan Penghimpunan Dana Dan Penyaluran Dana Serta Pelayanan Jasa Bank Syariah, pada Pasal 2, bank syariah dalam kegiatan penghimpunan dana, penyalurannya wajib menggunakan prinsip syariah.

Ketentuan Undang-Undang Nomor 10 Tahun 1998 Tentang Perubahan Undang-undang Nomor 7 Tahun 1992 Tentang Perbankan (selanjutnya ditulis UUP), merumuskan prinsip syariah yang terdapat pada Pasal 1 Angka (13), yaitu:

"Prinsip syariah adalah aturan perjanjian berdasarkan hukum Islam antara bank dengan pihak lain untuk menyimpan dana dan atau pembiayaan kegiatan usaha, atau kegiatan lainnya yang dinyatakan sesuai syariah, antara lain, pembiayaan berdasarkan prinsip bagi hasil (mudharabah), pembiayaan berdasarkan prinsip penyertaan mosal (musharakah), prinsip jual beli barang dengan memperoleh keuntungan (murabahah), atau pembiayaan barang modal berdasarkan prinsip sewa murni tanpa pilihan (ijarah), atau dengan adanya pilihan pemindahan kepemilikan atas barang yang disewa dari pihak bank oleh pihak lain (ijarah wa iqtinai)."

Prinsip-prinsip tersebut secara luas merupakan prinsip yang diterapkan dalam suatu produk perbankan syariah. Namun, Pasal 1 Angka 12 UUPS, dijelaskan bahwa "Prinsip syariah adalah prinsip hukum Islam dalam kegiatan perbankan berdasarkan fatwa yang dikeluarkan oleh lembaga yang memiliki kewenangan dalam penetapan fatwa di bidang syariah."

Dewan Syariah Nasional (selanjutnya ditulis DSN) mengeluarkan fatwa mengenai prinsip syariah yang terdapat pada perbankan syariah. Prinsip syariah yang dimaksud adalah; ${ }^{10} 10$ prinsip keadilan ('adl), keseimbangan (tawazun), kemaslahatan (maslahah) dan universalisme (alamiya). Undang-undang Nomor 21 Tahun 2008 Tentang Perbankan Syariah, merupakan payung hukum dalam operasional dan kegiatan perbankan syariah. Kegiatan usaha oleh bank syariah merupakan ruang lingkup Hukum Islam dalam arti khusus. Salah satu ruang lingkup hukum islam, yaitu: ${ }^{11} 11$ Muamalat (dalam arti khusus), mengatur masalah kebendaan dan hakhak atas benda, tata hubungan manusia dalam jual beli, sewa-menyewa, pinjam meminjam, perserikatan dan lain sebagainya. Demikian pula, Pasal 19 ayat (1) Huruf (c) menyatakan bahwa, "Kegiatan usaha Bank Umum Syariah meliputi: menyalurkan Pembiayaan bagi hasil berdasarkan Akad mudharabah, Akad musyarakah, atau Akad lain yang tidak bertentangan dengan Prinsip Syariah ......."

Prinsip-prinsip syariah yang dimaksudkan tersebut, secara garis besar sama dengan prinsip-prinsip syariah yang dimaksudkan dalam Pasal 2 Undang-Undang Nomor 21 Tahun 2008 Tentang Perbankan Syariah yang menjabarkan bahwa, "Perbankan Syariah dalam melakukan kegiatan usahanya berasaskan Prinsip Syariah, demokrasi ekonomi, dan prinsip kehati-hatian", dimana di dalam bagian Penjelasan Pasal 2 UUPS dijabarkan bahwa kegiatan usaha yang berasaskan prinsip syariah yang dimaksud di atas antara lain, adalah kegiatan usaha yang tidak mengandung unsur:

10 Rachmadi Usman, Produk dan Akad Perbankan Syariah di Indonesia, PT Citra Aditya Bakti, Bandung, 2009. Hlm. 19

11 Renny Supriyatni, Pengantar Hukum Islam, Widya Padjadjaran, Bandung, 2011. Hlm. 19. 
1. Riba, yaitu penambahan pendapatan secara tidak sah (batil) antara lain dalam transaksi pertukaran barang sejenis yang tidak sama kualitas, kuantitas, dan waktu penyerahan $(f a d h l)$, atau dalam transaksi pinjam-meminjam yang mempersyaratkan nasabah penerima fasilitas mengembalikan dana yang diterima melebihi pokok pinjaman karena berjalannya waktu (nasi'ah). Pengertian secara bahasa, riba adalah tambahan namun yang dimaksud riba dalam ayat Al-Quran (QS. Ar-Rum ayat 39) yaitu setiap penambahan yang diambil tanpa adanya suatu 'iwad (penyeimbang atau pengganti) yang dibenarkan syariah. Riba dalam segala bentuknya dilarang bahkan dalam ayat Al-Quran tentang pelarangan riba yang terakhir yaitu surat Al-Baqarah ayat 278-279 yang artinya:

"Hai orang-orang yang beriman takutlah kepada Allah dan tinggalkanlah sisa-sisa riba itu jika kamu orang beriman. Kalau kamu tiada memperbuatnya ketahuilah ada peperangan dari Allah dan Rasul-Nya terhadapmu dan jika kamu bertobat maka untukmu pokok-pokok hartamu kamu tidak menganiaya dan tidak pula teraniaya";

2. Maisir, yaitu transaksi yang digantungkan kepada suatu keadaan yang tidak pasti dan bersifat untung-untungan. ${ }^{12} 12$ Menurut pendapat Muhammad Ali as-Sayis adalah AL-maisir asalnya dari kata taisir yang berarti yang memudahkan, yaitu suatu cara pembagian yang didasarkan atas kesepakatan sebagaimana yang dilakukan pembagian dalam judi. ${ }^{13} 13 \mathrm{Al}-$ maisir atau judi adalah suatu permainan yang mengandung unsur taruhan yang dilakukan secara berhadap-hadapan atau langsung antara dua orang atau lebih ${ }^{14} 14$;

3. Gharar, yaitu transaksi yang objeknya tidak jelas, tidak dimiliki, tidak diketahui keberadaannya, atau tidak dapat diserahkan pada saat transaksi dilakukan kecuali diatur dalam syariah. Gharar menurut bahasa artinya keraguan, tipuan, atau tindakan yang bertujuan merugikan pihak lain. Pengertian gharar menurut ulama fikih Imam al-Qarafi sebagaimana dikutip oleh M. Ali Hasan adalah sebagai berikut: Imam al-Qarafi mengemukakan gharar adalah suatu akad yang tidak diketahui dengan tegas, apakah efek akad terlaksana atau tidak, seperti melakukan jual beli ikan yang masih dalam air (tambak). ${ }^{15} 15$ Larangan gharar dilarang dalam Islam berdasarkan pada al-Quran yang melarang memakan harta orang lain dengan cara batil, sebagaimana firman Allah dalam QS. An-Nisa ayat: 29, yang artinya:

"Hai orang-orang yang beriman, janganlah kamu saling memakan harta sesamamu dengan jalan yang batil, kecuali dengan jalan perniagaan yang berlaku dengan suka sama-suka di antara kamu. Dan janganlah kamu membunuh dirimu. Sesungguhnya Allah adalah Maha Penyayang kepadamu”;

4. Haram, yaitu transaksi yang objeknya dilarang dalam syariah. Haram adalah sesuatu yang secara tegas dilarang Allah untuk dikerjakan dan pelakunya diancam siksa serta hukumannya secara permanen di akhirat bahkan terkadang ditambah dengan sanksi di dunia;

5. Zalim, yaitu transaksi yang menimbulkan ketidakadilan bagi pihak lainnya. ${ }^{16} 16$ Zalim merupakan perbuatan yang dilarang oleh Allah Swt. dan termasuk dari salah satu dosardosa besar. Manusia yang berbuat zalim akan mendapatkan balasan di dunia dan siksa yang pedih di akhirat kelak. Sebagaimana firman Allah Swt. dalam QS. As-Syura ayat 42, yang artinya:

12 Idem.

13 Muhammad Ali as-Sayis, Tafsir Ayat Ahkam, Misra: Ali Assabais, 1953, hlm.207.

14 Ibrahim Hosen, Apa Itu Judi ?, Jakarta: Institut Ilmu Al-Quran, 1986, hlm.29.

15 M. Ali Hasan, Berbagai Macam Transaksi dalam Islam, Jakarta: PT Raja Grafindo Persada, 2003, hlm.147.

16 Idem. 
"Sesungguhnya dosa besar itu atas orang-orang yang berbuat zalim kepada manusia dan melampaui batas di muka bumi tanpa hak. Mereka itu mendapat azab yang pedih";

Selanjutnya bank syariah di Indonesia hanya menawarkan produk-produk perbankan Islam klasik, yang telah disetujui oleh para ahli fiqh seperti Mudharabah, Murabahah, Ijrah, dan lain-lain. ${ }^{17} 17$ Produk perbankan yang berada pada bank syariah diantaranya deposito, wadi'ah, giro, murabahah, mudharabah, dan musyarakah. Kurang berkembangnya produk bank syariah dikarenakan bank tetap harus berpegang pada prinsip syariah. Produk- produk Pembiayaan bank syariah merupakan penyediaan dana atau tagihan yang dipersamakan dengan itu berupa:

1. transaksi bagi hasil dalam bentuk mudharabah dan musyarakah;

2. transaksi sewa-menyewa dalam bentuk ijarah atau sewa beli dalam bentuk ijarah muntahiya bittamlik;

3. transaksi jual beli dalam bentuk piutang murabahah, salam, dan istishna';

4. transaksi pinjam meminjam dalam bentuk piutang qardh; dan

5. transaksi sewa-menyewa jasa dalam bentuk ijarah untuk transaksi multijasa berdasarkan persetujuan atau kesepakatan antara Bank Syariah dan/atau UUS dan pihak lain yang mewajibkan pihak yang dibiayai dan/atau diberi fasilitas dana untuk mengembalikan dana tersebut setelah jangka waktu tertentu dengan imbalan ujrah, tanpa imbalan, atau bagi hasil.

\section{Pembahasan}

\section{Inovasi Produk Perbankan Syariah}

Perbankan Syariah berkembang sejak diubahnya Undang-Undang Nomor 7 Tahun 1992 Tentang Perbankan, akan tetapi belum begitu pesat perkembangannya. Setelah UndangUndang Nomor 21 Tahun 2008 Tentang Perbankan Syariah keluar, perkembangan industri perbankan syariah sangat pesat sekali. Perbankan syariah di Indonesia tercatat urutan ke empat dari perkembangan perbankan syariah di dunia, dan perbankan syariah di Indonesia mampu bertahan mengkadapi krisis ekonomi pada masa Orde Baru. ${ }^{18} 18$ Seiring dengan perkembangan industri perbankan Syariah diIndonesia yang semakin pesat, maka perlu untuk dipahami segala hal yang berkaitan dengan industri perbankan syariah di Indonesia ini. Salah satu hal penting adalah inovasi produk industri perbankan syariah.

Perbankan syariah seiring dengan perkembangannya,dari waktu ke waktu membutuhkan pengembangan produk juga semakin bertambah. Inovasi dalam rangka pengembangan produk dan jasa perbankan yang baru dinilai penting karena masih banyak bentuk-bentuk layanan jasa keuangan yang perlu dikembangkan untuk memenuhi kebutuhan dunia usaha dan masyarakat secara umum yang terus berkembang. Dalam rangka memastikan produk dan jasa baru yang akan dikeluarkan, bank syariah dan Unit Usaha Syariah wajib menyampaikan rencana pengeluaran produk dan jasa baru tersebut kepada Bank Indonesia melalui salah satu dari dua mekanisme yaitu laporan rencana pengeluaran produk baru atau mengajukan permohonan persetujuan produk baru (izin).

Mekanisme pertama yaitu pelaporan produk diberlakukan untuk produk baru bank yang telah ditetapkan dalam Buku Kodifikasi Produk Perbankan Syariah. Bank melaporkan rencana pengeluaran produk tersebut kepada Bank Indonesia untuk mendapatkan penegasan paling lambat 15 hari sebelum produk baru dimaksud dikeluarkan. Produk baru yang belum Inovasi Produk Industri Perbankan Syariah di Indonesia ditetapkan dalam Buku Kodifikasi Produk Perbankan Syariah,diberlakukan mekanisme kedua.

17 Wardah Yuspin. Aspek Hukum dan Kelembagaan Perbankan Syariah. Genta publishing. Yogyakarta. 2016. Hlm. 47

18 Hartono Marjono, 2010, Petunjuk Praktis Menjalankan Syariat Islam Dalam Bermuamalah yang Sah Menurut Hukum Nasional, Jakarta: Studi Pres, hlm 35. 
Selanjutnya, dalam pemanfaatan dan optimalisasi Kodifikasi Produk Perbankan Syariah Internasional perlu adanya pengkajian dari DSN-MUI untuk memilih dan memilah produk dalam kodifikasi tersebut yang dapat dipertimbangkan untuk dikembangkan di Indonesia. Diantara produk yang memerlukan fatwa yang diusulkan sudah terdapat dalam kodifikasi produk internasional tersebut. Saat ini, industri perbankan secara umum diidentifikasi mengarah kepada permintaan terhadap layanan pinjaman cepat seperti kredit tanpa agunan dan kredit skala kecil (mikro). Hal yang sama terjadi pada perbankan syariah disebabkan target pasar yang sama dan adanya kecendrungan replikasi produk (product mirroring) perbankan syariah dari perbankan konvensional.

Produk tersebut, dapat menyebabkan peningkatan pembiayaan yang bersifat konsumtif. Oleh karena itu diperlukan produk penyeimbang yang mendukung sektor produktif. Selain itu, produk yang meningkatkan kebersamaan bank dan nasabah juga perlu dikaji dan dikembangkan, agar core product perbankan syariah yang merupakan sharing economics tetap dapat dipertahankan. Untuk keperluan tersebut, kajian mengenai produk bagi hasil, yaitu musyarakah mutanaqisah dan mudharabah muqayyadah harus giat dilaksanakan. Tentu saja upaya pengkajian seperti ini mesti melibatkan semua pihak, termasuk di dalamnya industri dan lembaga pendukung.

Selain itu dalam rangka percepatan pertumbuhan industri, produk-produk yang telah dipasarkan di negara lain harus terus dikaji untuk penerapannya di tanah air. Keinginan masyarakat dan dunia industri tersebut, ditindaklanjuti sebuah komite kerja telah dibentuk oleh Bank Indonesia yang melibatkan lembaga terkait seperti Dewan Syariah Nasional-MUI dan Ikatan Akuntan Indonesia. Komite membahas antara lain kemungkinan penerapan produkproduk tersebut di tanah air, dan dapat mengeluarkan rekomendasi kepada lembaga terkait agar memperoleh penjelasan dari sisi syariah, akuntansi dan lainnya. ${ }^{19} 19$

Strategi pemasaran produk mesti diselenggarakan dengan melakukan aliansi strategis dengan media massa (radio, televisi dan media cetak) dan penyelenggara kegiatan (eventorganizer) berupa pameran (ехро), agar produk tersebut dikenal luas dan langsung dirasakan manfaatnya oleh masyarakat luas. Dalam ekspo tertentu misalnya masyarakat dapat langsung mendaftar untuk kartu kredit syariah atau melakukan permohonan pembiayaan untuk pembelian produk syariah yang sedang dipamerkan. Strategi bank syariah tersebut biasanya mendapat banyak keberhasilan, baik dalam peningkatan portofolio maupun pemasaran produk baru. Produkproduk tersebut, antara lain Musharaqah Mutanaqisah (MMq), Gadai Syariah (Rahn), Kafalah, Hawalah dan lain-lain.

\section{Kendala-kendala Dalam Inovasi Produk Industri Perbankan Syariah}

Prinsip bagi hasil pada Bank Syariah dapat menciptakan iklim investasi yang sehat dan adil karena semua pihak dapat saling berbagi baik keuntungan maupun potensi risiko yang timbul sehingga akan menciptakan posisi yang berimbang antara bank dan nasabahnya. Dalam jangka panjang, hal ini akan mendorong pemerataan ekonomi nasional karena hasil keuntungan tidak hanya dinikmati oleh pemilik modal saja, tetapi juga oleh pengelola modal. Disamping itu, Perbankan Syariah sebagai salah satu sistem perbankan nasional memerlukan berbagai sarana pendukung agar dapat memberikan kontribusi yang maksimum bagi pengembangan ekonomi nasional.

Survei yang dilakukan oleh Bank Indonesia dan Mars Company selama periode 20002009 pada tahun 2008 mengungkapkan bahwa hampir semua orang Indonesia mendukung gagasan perbankan Islam. Aturan yang telah dikeluarkan oleh Bank Indonesia semata-mata mendukung pertumbuhan industri perbankan, khususnya perbankan syariah. Beberapa macam Bank Syariah yang berkembang di Indonesia. Diantaranya sebagai berikut: ${ }^{20}$

19 Bank Indonesia, Laporan Pengembangan Perbankan Syariah 2015, Jakarta: Direktorat Perbankan Syariah, 2015.hal 42.

20 Ibid. Hlm. 44 
a. Bank Umum Syariah. Bank Umum Syariah adalah bank syariah yang dalam kegiatannya memberikan jasa dalam lalu lintas pembayaran (Pasal 1 Ayat 8 UUPS).

b. Bank Pembiayaan Rakyat Syariah. Bank Pembiayaan Rakyat Syariah adalah bank syariah yang dalam kegiatannya tidak memberikan jasa dalam lalu lintas pembayaran (Pasal 1 Ayat 9 UUPS).

Selanjutnya inovasi produk industri perbankan syariah dalam pelaksanaannya sangat sulit untuk dilakukan karena terpaku pada prinsip syariah yang apabila dikembangkan maka dapat muncul perdebatan. Saat ini belum dapat dikatakan bagi bank syariah untuk menerapkan secara murni apa yang terdapat dalam syariah, bahkan dapat dikatakan bank syariah adalah bank konvensional yang "disyariahkan" 2121 dalam segala operasionalnya, baik produknya maupun transaksinya. Perdebatan tersebut, yang dihindari oleh pihak bank syariah dalam menegakkan prinsip syariah. Selain itu, Bank syariah dalam menetapkan bagi hasil berdasarkan bagi pendapatan (revenue sharing) bukan berdasarkan prinsip bagi untung dan rugi (profit and loss sharing), dan bank sulit untuk membagi hasil/keuntungan karena skala pembiayaan sangat kecil. Sebagaimana yang diharapkan dalam mencapai tujuan menunjang pelaksanaan pembangunan nasional, Perbankan Syariah tetap berpegang pada Prinsip Syariah secara menyeluruh (kaffah) dan konsisten (istiqamah).

\section{Penutup}

\section{Kesimpulan}

a. Strategi Inovasi Produk Industri Perbankan Syariah Dalam Mengembangkan Perekonomian di Indonesia Berdasarkan Undang-Undang Perbankan Syariah yakni perbankan syariah harus mampu mengeluarkan produk-produk inovasi industri perbankan syariah (antara lain Musharaqah Mutanaqisah (MMq), Gadai Syariah (Rahn), Kafalah, Hawalah dan lain-lain), agar mampu bersaing dengan industri perbankan lainnya, perbankan syariah harus mampu meningkatkan Sumber Daya Insani, dan mampu membuat strategi pemasaran produk yang diselenggarakan dengan melakukan aliansi strategis, seperti: media massa (radio, televisi dan media cetak) dan penyelenggara kegiatan (event organizer) berupa pameran (expo), agar produk tersebut dikenal luas dan langsung dirasakan manfaatnya oleh masyarakat luas.

b. Inovasi produk industri perbankan syariah dalam pelaksanaannya sangat sulit untuk dilakukan karena terpaku pada prinsip syariah yang apabila dikembangkan maka dapat muncul perdebatan. Selain itu, Bank syariah dalam menetapkan bagi hasil berdasarkan bagi pendapatan (revenue sharing) bukan berdasarkan prinsip bagi untung dan rugi (profit and loss sharing).

\section{Saran}

a. Mengingat bahwa penyaluran dana Pembiayaan bersumber dari dana masyarakat yang disimpan pada Bank Syariah dan Unit Usaha Syariah (UUS), risiko yang dihadapi Bank Syariah dan Unit Usaha Syariah (UUS) dapat berpengaruh pula kepada keamanan dana masyarakat tersebut. Oleh karena itu, untuk memelihara kesehatan

21 Renny Supriyatni, Opcit, hlm 6-7, sebagaimana dikutip dari Cecep Maskanul Hakim, "Problem Pengembangan Produk Dalam Bank Syariah", Makalah, Tim Penelitian dan Pengembangan Bank Syariah_DPNP, hlm.2. Mulya E Siregar dan Nasirwan (Peneliti Senior Biro Perbankan Syariah BI) Posted by shariahlife on January 16th, 2007, "Tantangan Perbankan Syariah", Sumber Republika:" Berdasarkan UU No 7 Tahun 1992 itu bank syariah dipahami sebagai bank bagi hasil. Selebihnya bank syariah harus tunduk kepada peraturan perbankan umum yang berbasis konvensional. Karenanya manajemen bank-bank syariah cenderung mengadopsi produk-produk perbankan konvensional yang "disyariahkan", dengan variasi produk yang terbatas. Akibatnya tidak semua kebutuhan masyarakat terakomodasi dan produk yang ada tidak kompetitif terhadap semua produk bank konvensional. 
dan meningkatkan daya tahannya, bank diwajibkan menyebar risiko dengan mengatur penyaluran pemberian pembiayaan Syariah, pemberian jaminan ataupun fasilitas lain sedemikian rupa sehingga tidak terpusat pada nasabah debitur atau kelompok nasabah debitur tertentu.

b. Perangkat bank syariah dalam melaksanakan pengawasan baik bersifat Internal maupun ekstenal Dewan Syariah Nasional (DSN), Komite (Depag, BI dan unsur masyarakat), Otoritas Jasa Keuangan (OJK), DPS dan Nasabah, memberikan pengawasan yang optimal. Hal tersebut akan memberikan dampak positif yakni menjalankan/ terlaksananya kepatuhan syariah (syariah compliance) yang kewenangannya berada pada Majelis Ulama Indonesia (MUI) yang direpresentasikan melalui Dewan Pengawas Syariah (DPS) yang harus dibentuk pada masing-masing Bank Syariah dan Unit Usaha Syariah (UUS) akan efektif.

\section{Daftar Pustaka}

Arsyad, Lincolin, 2007, Clustering Industri, Pengantar Perencanaan dan Pembangunan Ekonomi Daerah, BPFE, Yogyakarta

Bank Indonesia, Laporan Pengembangan Perbankan Syariah 2015, Jakarta: Direktorat Perbankan Syariah, 2015

Burhanuddin S, Aspek Hukum Lembaga Kauangan Syariat, Graha Ilmu, Yogyakarta. 2010

Dirdjojuwono, Roestanto W, 2003, Kawasan Industri Indonesia (Sebuah Konsep Perencanaan Dan Aplikasinya), Pustaka Wirausaha Muda, Bogor

Fatwa-fatwa Dewan Syariah Nasional (DSN) - Majelis Ulama Indonesia (MUI)

Freeman, R E, 1984, Strategic Management: A Stakeholder Aproach, Bpston, Ma Pitman

Hartono Marjono, 2010, Petunjuk Praktis Menjalankan Syariat Islam Dalam Bermuamalah yang Sah Menurut Hukum Nasional, Jakarta: Studi Pres. Jakarta: ELIPS.1999

Peraturan Bank Indonesia 10/16/PBI/2008 Tentang Perubahan Peraturan Bank Indonesia Nomor 9/19/PBI/2007 Tentang Pelaksanaan Prinsip Syariah

Peraturan Bank Indonesia Nomor 11/3/PBI/2009 Tentang Bank Umum Syariah (BUS)

Peraturan Bank Indonesia Nomor 11/10/PBI/2009 Tentang Unit Usaha Syariah (UUS)

Pervaiz K. Ahmed and Charles D. Shepherd, 2010, Internal Marketing, Routlege

Prayoga, Ayudha D, et all, Industri dan Hukum yang Mengatur di Indonesia

Rachmadi Usman, Produk dan Akad Perbankan Syariah di Indonesia, PT Citra Aditya Bakti, Bandung, 2009

Renny Supriyatni, Sistem Bagi Hasil Dengan Pembagian Untung dan Rugi, Dapat Memberi Keadilan Bagi Nasabah \& Bank Syariah, Unpad Press, Bandung, 2009

Renny Supriyatni, Pengantar Hukum Islam, Widya Padjadjaran, Bandung, 2011

Tedjasuksmana, Budianto. 2014. Potret Indonesia Menghadapi Masyarakat Ekonomi ASEAN 2015. Jurnal UKWMS. ISSN No: 1978-6522

Undang-undang Nomor 21 Tahun 2008 Tentang Perbankan Syariah

Wardah Yuspin, Aspek Hukum dan Kelembagaan Perbankan Syariah. Genta publishing. Yogyakarta. 2016 